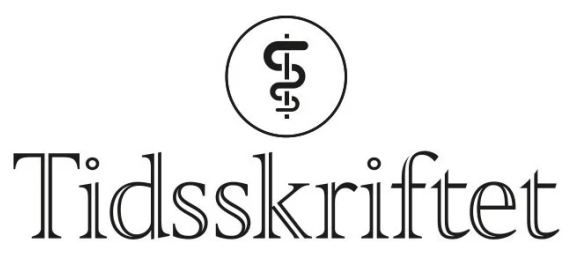

DEN NORSKE LEGEFORENING

\title{
Norge må si ja til rettferdig tilgang til covid-19-vaksiner
}

DEBATT

\section{KATARINA FOSS-SOLBREKK}

katarina.foss-solbrekk@law.ox.ac.uk

Katarina Foss-Solbrekk er ph.d.-student i juss ved Oxford University. Hun har en bachelor fra Edinburgh University, og master fra både Leiden University og Stockholms Universitet. Forfatteren har fylt ut ICMJE-skjema og oppgir ingen interessekonflikter.

\section{Menneskers helse er viktigere enn produsentenes rettighetsbeskyttelse av covid-19-vaksiner.}

2. oktober 2020 foreslo India og Sør-Afrika for Verdens handelsorganisasjon (WTO) å unnta alle relevante covid-produkter fra legemiddelfirmaenes immaterielle rettigheter. Dette vil innebærer at produsentenes rettighetsbeskyttelse oppheves. Forslaget ble støttet av over 100 land. I mai ga både Biden-administrasjonen i USA og Europaparlamentet sin støtte til forslaget som vil åpne for at flere land kan produsere covid-19-vaksiner.

Forslaget ble fremmet etter at vestlige land hadde kjøpt opp vaksiner før utviklingslandene rakk å komme til forhandlingsbordet med de farmasøytiske selskapene. Biden og Europaparlamentets støtte til unntaket er historisk, men vil henge i en tynn tråd hvis ikke WTO-medlemmene enes.

\section{"I slutten av april hadde $0,3 \%$ av vaksinene blitt distribuert til utviklingsland, til tross for at tusenvis dør hver dag i land som Brasil, India og Nepal»}

Unntaket kan potensielt forbedre den globale fordelingen av vaksiner. 18. januar 2021 informerte Tedros Ghebreyesus, generaldirektøren i Verdens helseorganisasjon (WHO), at 39 millioner vaksinedoser var blitt satt i industriland, mens kun 25 doser hadde nådd borgere i utviklingsland (1). Lite har skjedd siden. I slutten av april hadde $0,3 \%$ av vaksinene blitt distribuert til utviklingsland (2 2 , til tross for at tusenvis dør hver dag i land som Brasil, India og Nepal.

\section{Norge blokkerer}


Norge er et av landene som blokkerer India og Sør-Afrika sitt forslag, og det er usikkert om Norge vil endre retning. Ifølge statssekretær Jens Frølich Holte i Utenriksdepartementet er ikke patenter «bremsen», men «teknisk infrastruktur hos mulige produsenter, kunnskap om svært komplisert vaksineproduksjon, og utfordringer med å nå kvalitetskravene som bremser utbredelsen. Dette løses best gjennom samarbeid mellom produsenter og frivillige ordninger» (3).

Dette kan nok diskuteres. Konkurrentene til originalprodusentene hjelper allerede til med produksjon av vaksiner. Eksempelvis har Sanofi annonsert at de vil hjelpe Pfizer i å produsere 100 millioner vaksiner til Europa (4). Merck hjelper Johnson \& Johnson med å produsere sin vaksine i USA (5). Flere fabrikker rundt i verden meddeler at de står klare til å produsere vaksiner (므). I tillegg rapporteres det at firmaene Biolyse i Canada, Incepta i Bangladesh, Teva i Israel og Bavarian Nordic i Danmark nylig tilbød å produsere vaksiner, men farmasøytiske firmaer takket nei (7.). Er produksjonsutfordringer da et faktum eller et valg? Skulle ikke India som i dag produserer $60 \%$ av vaksinene i verden være i stand til å produsere flere covid-vaksiner?

Verdens helseorganisasjon ønsker også å utvikle kunnskapsdelingen slik at vaksineteknologien kan deles med flere produsenter i utviklingsland ( $\underline{8})$.

\section{Unntaket kan hjelpe utviklingsland}

Kunnskapen kan deles. Kapasiteten kan utbygges. Men dette hjelper lite når rettighetene til å produsere uteblir. Unntaket vil gi flere selskaper i utviklingsland rett til å produsere, samt sikkerhet for ikke å bli saksøkt for brudd på immaterielle rettigheter. Unntaket kan også tiltrekke investeringer som trengs til å bygge nye fabrikker eller restrukturere gamle fabrikker for å produsere vaksiner.

«Kunnskapen kan deles. Kapasiteten kan utbygges. Men dette hjelper lite når rettighetene til å produsere uteblir»

Uavhengig av det foreslåtte unntaket må farmasøytiske selskaper være villige til å dele teknologien med andre. Et unntak kan gi utviklingsland den internasjonale støtten de trenger i forhandlinger uten frykt for konsekvenser. Utviklingsland møter ofte motstand hvis de lemper på immaterielle rettigheter for å beskytte menneskers rett til helse. Under HIV/AIDS-epidemien på 1990-tallet mistet millioner av mennesker i utviklingsland livet, til tross for at essensielle medisiner eksisterte på markedet. Medisinene var dyre og lokale produsenter fikk heller ikke den gangen lov til å produsere eller importere billige og generiske medisiner. Da Sør-Afrika prøvde og øke medisinsk tilgang under HIV/AIDS-krisen ved å innføre tvangslisens i lovverket sitt, ble de saksøkt av 40 farmasøytiske firmaer (9.). EU sendte et truende brev om at Sør-Afrika brøt internasjonale handelsforpliktelser og USA innførte handelssanksjoner på sørafrikanske produkter (9). Etter at Thailand godkjente tvangslisenser på to medisiner i 2006 og 2007 trakk produsenten Abbott tilbake legemidlene som avventet registrering og nektet å registrere nye legemidler i Thailand (10 $)$.

Historien ser ut til å gjenta seg. Det er på tide at vi støtter forslaget om unntak for produsentenes rettigheter på covid-19-vaksiner og derav beskytter retten til helse.

\section{LITTERATUR}

1. World Health Organisation. WHO Director-General's opening remarks at 148 th session of the Executive Board. https://www.who.int/director-general/speeches/detail/who-director-general-sopening-remarks-at-148th-session-of-the-executive-board Lest 3.6.2021. 
2. World Health Organisation. ACT-Accelerator one year on. https://www.who.int/news/item/23-042021-act-accelerator-one-year-on Lest 3.6.2021.

3. Johnson AB, Holmes MCS. Vaksine-drama i WTO: Fattige land krever fri vaksineproduksjon. VG 5.5.2021. https://www.vg.no/nyheter/utenriks/i/Vqma93/vaksine-drama-i-wto-fattige-land-krever-frivaksineproduksjon Lest 3.6.2021.

4. Sanofi. Sanofi to provide support to BioNTech in manufacturing their COVID-19 vaccine to help address public health needs. https://www.sanofi.com/en/media-room/press-releases/2021/2021-01-2707-30-0o Lest 3.6.2021.

5. Rowland C, McGinley L. Merck will help make Johnson \& Johnson coronavirus vaccine as rivals team up to help Biden accelerate shots. Washington Post 3.3.2021.

https://www.washingtonpost.com/health/2021/03/02/merck-johnson-and-johnson-covid-vaccinepartnership/ Lest 3.6.2021.

6. Lerner S, Fang L. Factory owners around the world stand ready to manufacturer covid-19 vaccines. The Intercept 29.4.2021. https://theintercept.com/2021/04/29/covid-vaccine-factory-production-ip/? utm_campaign=theintercept\&utm_medium=social\&utm_source=twitter Lest 3.6.2021.

7. Furlong A. Big vaccine makers reject offers to help produce more jabs. Politico 14.5.2021. https://www.politico.eu/article/vaccine-producers-reject-offers-to-make-more-jabs/ Lest 3.6.2021.

8. World Health Organisation. Establishment of a COVID-19 mRNA vaccine technology transfer hub to scale up global manufacturing. https://www.who.int/news-room/articles-detail/establishment-of-acovid-19-mrna-vaccine-technology-transfer-hub-to-scale-up-global-manufacturing Lest 3.6.2021.

9. 't Hoen E. TRIPS, pharmaceutical patents, and access to essential medicines: a long way from Seattle to Doha. Chic J Int Law 2002; 3: 27-46. [PubMed]

10. Jain D, Darrow JJ. An exploration of compulsory licensing as an effective policy tool for antiretroviral drugs in India. Health Matrix Clevel 2013; 23: 425-57. [PubMed]

Publisert: 28. juni 2021. Tidsskr Nor Legeforen. DOI: 10.4045/tidsskr.21.0425

Mottatt 20.5.2021, første revisjon innsendt 31.5.2021, godkjent 3.6.2021.

(C) Tidsskrift for Den norske legeforening 2023. Lastet ned fra tidsskriftet.no 26. april 2023. 